\title{
EKSPLORASI VISUAL FUTURISTIK UNTUK PERANCANGAN ANIMASI PENDEK DAMPAK PENGGUNAAN TEKNOLOGI BERLEBIHAN DALAM KELUARGA
}

\author{
Olivia Alethea $^{1)}$, Frans Santoso ${ }^{2)}$ \\ School of Design, Universitas Bina Nusantara \\ Kav 21, Alam Sutera Jalan Jalur Sutera Barat Panunggangan Timur, RT.001/RW.004, Panunggangan, \\ Kec. Pinang, Kota Tangerang, Banten 15143
}

Email: olivia.alethea@binus.ac.id

\begin{abstract}
Abstrak
Penggunaan teknologi secara berlebihan dapat menimbulkan berbagai hal negatif merupakan suatu hal yang sudah diketahui oleh masyarakat umum. Salah satu efek negatif yang terbentuk karena hal ini adalah hubungan sosial yang berkurang antarindividu, terutama hubungan dengan anggota keluarga. Banyak penelitian telah membuktikan pentingnya hubungan sosial dengan kesehatan mental seseorang, terutama hubungan yang paling dekat dengan individu tersebut film pendek animasi ini bertujuan untuk menghibur serta menginformasikan efek penggunaan teknologi yang berlebihan yang dapat berdampak pada hubungan dalam keluarga. Penelitian yang dilakukan akan menggunakan metode penelitian dokumen, observasi, dan wawancara dengan menganalisis berbagai sumber data dan referensi visual. Hasil yang direncanakan berupa workbook visual yang akan digunakan sebagai dasar pembuatan animasi pendek tersebut.
\end{abstract}

Kata kunci: Teknologi, Keluarga, Hubungan Sosial, Animasi Pendek

\begin{abstract}
Excessive use of technology can cause various negative effects, which is an already known fact to the public. One of the negative effects formed because of this is the rapidly decreasing social connections made between individuals, especially with family members. A lot of studies has proven the importance of social connections to one's mental health especially those closest to that individual. The short animation will tell the story about a family of technology addicts living in the future, where technological inventions are way more advanced. This animated short aims to entertain as well as inform the effects of excessive technology use may have inside a family with a bit of an exaggeration. The research itself will use the method of document research, observation, and interview by analyzing various sources of data and visual references. The planned result or output is in the form of a visual workbook that will be used as the basis for making the short animation.
\end{abstract}

Key words: technology, family, social connections, short animation

Correspondence author: Olivia Alethea, olivia.alethea@binus.ac.id, Banten, and Jakarta

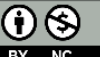

This work is licensed under a CC-BY-NC 


\section{PENDAHULUAN}

Teknologi telah menjadi bagian penting dari kehidupan sehari-hari. Sebab tujuan dari penciptaan teknologi adalah untuk mempermudah hidup manusia. Sebagai jalan komunikasi, bisnis, edukasi, transaksi dan lain sebagainya dapat dilakukan secara online berkat berkembangya teknologi digital. Dalam hal ini, teknologi berkembang sangat cepat untuk beradaptasi dengan berbagai situasi yang dihadapi oleh masyarakat. Namun, sudah menjadi suatu pengetahuan umum bahwa memiliki gaya hidup yang terlalu bergantung pada teknologi bukanlah hal yang baik.

Ketika berbicara dengan pengaruh teknologi dengan kehidupan sosial manusia, meskipun teknologi digital telah memungkinkan manusia untuk berinteraksi satu dengan yang lain bahkan sejauh dengan penduduk negara lain, tetapi dapat dikatakan juga kalau masyarakat sekarang menjadi kurang aktif secara sosial. Salah satu hubungan sosial yang menderita dari masalah ini, adalah hubungan dengan orang-orang yang dekat terutama keluarga dan teman. Anak-anak pertama kali belajar tentang hubungan dari keluarga sendiri. Keluarga berperan sebagai contoh agar mereka mulai menemukan bagaimana membangun hubungan yang baik sepanjang hidup mereka. Anak-anak yang memiliki model hubungan yang sehat dari keluarganya akan lebih mampu menciptakan hubungan tersebut di luar keluarganya.

Oleh karena itu, penulis ingin mengeksplorasi lebih lagi mengenai bagaimana penggunaan teknologi secara terus-menerus dapat memengaruhi hubungan sosial yang dimiliki dengan keluarga. Bagaimana penggunaan teknologi yang berlebihan dapat mempengaruhi hubungan dalam keluarga, terutama di tengah perkembangan teknologi digital yang sangat cepat ini. Bersama dengan itu, penulis juga ingin menjabarkan berbagai bagian teknologi yang sesuai dengan tren masyarakat kini dan melihatnya dari berbagai sisi negatif dan sisi positifnya.

Kata "teknologi" berasal dari dua kata dalam bahasa Yunani yaitu techne dan logos. Kata techne berarti keterampilan, cara atau keahlian sedangkan logos memiliki arti ilmu. Jadi kedua kata dasarnya teknologi memiliki definisi yaitu cara melakukan sesuatu untuk memenuhi kebutuhan manusia dengan bantuan akal dan alat yang digunakan untuk mempermudah pekerjaan manusia. Teknologi akan terus berkembang, hal-hal yang dulunya memiliki fungsi yang lebih sederhana, sekarang diberikan berbagai macam aplikasi sehingga nilai dan fungsinya meningkat. Contoh termudah dari evolusi teknologi yang cepat adalah handphone. Ancok, dkk (2017) menggambarkan bagaimana besarnya keterlibatan teknologi informasi akan terus berkembang dalam kehidupan manusia. Pertama, produk yang digerakkan sistem komputer. Pada masa depan produk-produk kebutuhan hidup manusia sehari-hari akan menjadi produk yang cerdas (smart product). Smart product adalah produk yang telah memiliki komponen inteligensi manusia, yang sekarang diketahui secara umum sebagai Artificial Intelligence (AI).

Kecanduan teknologi dapat didefinisikan sebagai tingkah obsesif terhadap teknologi yang terus dilakukan walaupun mengetahui konsekuensi negatif saat menggunakannya dalam waktu yang berlebihan. Ketergantungan yang berlebihan pada teknologi merupakan salah satu faktor dalam bentuknya kecanduan pada teknologi. Walaupun dalam dunia sosial modern sekarang ini, manusia membutuhkan teknologi untuk bertahan hidup, ketergantungan yang berlebihan pada teknologi mencapai tingkat kecanduan dapat berdampak pada kondisi mental dan kemampuan sosial yang dimiliki oleh seseorang.

Salah satu perbedaan besar antara teknologi sebelumnya dan teknologi digital saat ini adalah waktu, jumlah waktu masyarakat menghabiskan aktivitas sehari-harinya dengan hanya memandangi sebuah layar berbeda dengan tanggapan masyarakat pada penemuan teknologi sebelumnya seperti buku, bioskop, radio, dan bahkan TV. Ahli futurologi bernama Richard Watson memiliki pendapat kalau sejauh mana teknologi digital mendominasi hidup manusia membuat suatu perbedaan penting, "Sebagai manusia, kami selalu berusaha untuk menemukan hal-hal baru. Kami selalu mengkhawatirkan hal-hal baru dan kami selalu mengeluh tentang generasi muda. Tentunya sebagian besar dari dugaan ini digabungkan dengan kecemasan terhadap berkembangnya teknologi? Saya pikir jawabannya kali ini sedikit berbeda. Layar digital ada di mana-mana. Menghasilkan generasi yang kecanduan.".

Greenfield (2015) berpendapat kalau teknologi digital dibandingkan dengan penemuan dari 
era sebelumnya menghasilkan suatu pergeseran dari fungsinya sebagai alat menjadi suatu bentuk dari tujuan. Teknologi digital memiliki potensi untuk menjadi tujuan, bukan hanya sebagai alat untuk mempermudah hidup keseharian tetapi sebagai suatu bentuk dari gaya hidup. Dalam bersosialisasi hingga berbelanja, bekerja, belajar, dan sebagai hiburan, semua yang kita lakukan setiap hari sekarang dapat dilakukan hanya melalui teknologi digital. "Untuk pertama kalinya, hidup di depan layar komputer mengancam untuk mengalahkan kehidupan nyata". Beberapa bentuk dari teknologi digital yang telah mengambil alih kehidupan masyarakat adalah sebagai berikut:

1. Smartphone: Telepon diciptakan agar kita bisa berkomunikasi dengan orang lain pada jarak tertentu dan jarak itu berkembang hingga sekarang kita bisa berkomunikasi dengan sangat mudah dengan penduduk negara lain. Teknologi pada dasarnya telah mengubah cara kita berkomunikasi, berbicara dengan orang lain secara langsung atau melalui telepon bukan lagi cara paling umum bagi kita untuk berinteraksi. Tren ini akan terus berlanjut seiring kemajuan teknologi dan kita melangkah lebih jauh ke era digital. Terdapat sebuah penelitian yang membuktikan kalau dukungan emosional yang dapat diberikan oleh alat-alat komunikasi ini ternyata sangat rendah. Para peneliti di University of Wisconsin-Madison melakukan percobaan di mana beberapa remaja diberikan tugas yang memunculkan rasa stres, dan kemudian dihibur oleh orang tua mereka melalui telepon, secara langsung, melalui SMS, atau tidak ada kontak orang tua sama sekali. Kemudian hasil dari penelitian tersebut menunjukkan kalau remaja yang berbicara dengan orang tuanya melalui telepon atau secara langsung mengalami penurunan stres, dan yang menerima SMS tidak mengalami pengurangan stres. Percobaan ini menunjukkan kalau meskipun teknologi memberikan cara yang jauh lebih mudah untuk berkomunikasi, tidak berarti bahwa sebenarnya berbicara dengan orang, bertemu dan mendengarkan suaranya menjadi tidak relevan lagi, dan hal tersebut dapat berdampak pada kondisi mental seseorang.

2. Media Sosial: Seorang psikolog membuat penelitian pada berbagai situs media sosial yang mungkin memicu pelepasan dopamin. Weinschenk (2014) mendefinisikan dopamin sebagai bahan kimia yang ditemukan di seluruh tubuh kita. Dalam otak, dopamin terlibat dalam banyak perilaku manusia, termasuk berpikir, bergerak, tidur, suasana hati, perhatian, motivasi, pencarian, dan penghargaan. Dopamin menyebabkan manusia untuk memiliki perasaan menginginkan, dan mencari. Rasa keinginan tersebutlah yang menjadi pendorong untuk bertindak. Berdasarkan media sosial dapat mengakibatkan kecanduan karena memberikan kepuasan instan, kemampuan untuk berhubungan dengan orang lain dengan segera serta kemungkinan mendapatkan tanggapan dalam beberapa detik dan menawarkan sensasi berantisipasi. Studi neuroimaging menunjukkan stimulasi yang lebih tinggi ketika seorang mengantisipasi sesuatu. Demikian pula rasa antisipasi yang dialami terhadap tweet, chat, e-mail, atau komentar baru. Perhatian dan persetujuan dari orang lain merupakan suatu hal yang dibutuhkan oleh setiap indivdu. Oleh karena itu, masyarakat zaman sekarang mencari rasa perhatian dan persetujuan tersebut dalam situs-situs media sosial seperti Twitter, Facebook, dan Instagram. Walau begitu terdapat perbedaan antara bersosialisasi secara online dan bersosialisasi secara langsung, yang berdampak pada tingkat empati yang dimiliki oleh seseorang. Kemampuan untuk peduli dan berbagi pengalaman emosional bersama dengan orang lain adalah sesuatu yang membedakan manusia dengan makhluk hidup lainnya. Penelitian telah menemukan bahwa bahkan bayi dan balita menunjukkan perilaku empati. Namun, perkembangan empati memerlukan banyak waktu, serta pengalaman untuk bersosialisasi secara langsung dan lingkungan juga memainkan peran penting dalam menentukan kemampuan dalam berempati untuk mengidentifikasi, menilai, dan mengelola emosi diri sendiri maupun orang lain. Seperti yang dikatakan oleh psikolog yang bernama Larry Rosen, "Jika kita menyakiti perasaan seseorang tetapi tidak dapat melihat reaksi orang tersebut, akan terdapat kekurangan petunjuk yang memadai untuk memahami apa yang telah kita lakukan untuk meminta maaf atau mengambil tindakan kompensasi lainnya. Waktu yang 
dihabiskan untuk menggunakan teknologi adalah waktu yang dihabiskan jauh dari dunia nyata dan orang-orang nyata. Melalui melihat orang lain atau mendengar suara mereka kita dapat mencoba untuk memahami bagaimana perasaan mereka. Terlalu banyak waktu yang difokuskan pada dunia dua dimensi jaringan sosial mungkin memengaruhi kemampuan untuk berempati dengan orang lain, membentuk hubungan yang berarti, dan mendapatkan hasil yang terbaik dari hubungan mereka".

3. Game: Pada tahun 2018, World Health Organizations (WHO) resmi menetapkan kecanduan game atau gaming disorder ke dalam versi terbaru International Statistical Classification of Diseases (ICD-11). ICD merupakan daftar klasifikasi medis yang berisi daftar penyakit beserta dengan gejala, tanda-tanda, dan penyebabnya. Dalam ICD-11, gaming disorder didefinisikan sebagai pola perilaku bermain game (baik game online atau video game) yang ditandai dengan ketidakmampuannya seseorang dalam mengontrol diri dan waktu, prioritas yang tertinggi diberikan pada bermain game dibandingkan dengan melakukan kegiatan aktivitas lain. Terdapat 3 karakteristik utama yang menunjukkan kalau seseorang memiliki game disorder, pertama, tidak dapat mengendalikan keinginan bermain game, kedua, lebih memprioritaskan bermain game dibandingkan melakukan kegiatan atau aktivitas lainnya, dan ketiga ketika seseorang terus bermain game meski mengetahui akan adanya konsekuensi negatif yang jelas terlihat. (Putri, 2018)

Keluarga terbentuk karena adanya ikatan darah, perkawinan, dan proses adopsi. Keluarga akan menjadi sarana utama untuk mengembangkan fisik, mental, emosional, dan kehidupan sosial setiap anggotanya. Anak-anak dilahirkan dan dibesarkan oleh orang tua, dan bagaimana suatu keluarga berfungsi berbeda dari satu rumah tangga ke rumah tangga lainnya. Keluarga seharusnya menjadi tempat dan sarana utama bagi anak untuk mengembangkan fisik, mental, emosional, dan kehidupan sosialnya. Baik orang tua maupun anak harus bekerja sama untuk mewujudkan lingkungan yang sehat dalam rumah tangganya. Bagian dari teknologi yang mudah ditemukan dalam kehidupan sehari-hari saat ini adalah teknologi digital. Baik dalam pendidikan, informasi, hiburan, bisnis, teknologi digital mencakup semuanya. Seorang ahli teknologi dari Amerika bernama Marc Prensky, menciptakan istilah Digital Native yang ditentukan oleh kemampuan dan keakraban seseorang dengan teknologi digital. Sebaliknya, Digital Immigrant adalah orang-orang yang telah mengadopsi banyak aspek teknologi, tetapi masih belum terbiasa. Untuk saat ini dapat dikatakan kalau orang tua kemungkinan besar adalah Digital Immigrant dan anak-anak mereka adalah Digital Natives. Digital Immigrant masih mempelajari potensi besar dari teknologi ini di masa dewasa, kebanyakan penemuan digital dikenalkan kepada anak-anaknya pada usia yang masih muda. Perbedaan antara generasi seperti ini sering kali mempersulit orang tua untuk mengetahui cara terbaik untuk mendekati situasi yang mereka anggap sebagai masalah, seperti penggunaan teknologi digital yang berlebihan. Sebaliknya, anak-anak dapat memiliki perasaan disalahpahami karena mereka anggap orang tua tidak pantas dan ketinggalan zaman untuk jaman modern saat ini. Setiap individu, dewasa dan anak sekarang memiliki berbagai perangkat digital yang mereka gunakan untuk hiburan, sosialisasi, dan informasi. Sekarang dunia digital dapat menawarkan berbagai konteks alternatif untuk mengatur kecepatan, menetapkan standar dan nilai, menawarkan percakapan, dan memberikan hiburan, sementara waktu untuk berhubungan dengan keluarga semakin berkurang.

Film dan animasi yang berbeda telah mencoba untuk memvisualisasikan seperti apa gambaran masa depan, dan tergantung pada bagaimana alur cerita berjalan, pandangan dari dunia yang futuristik dapat berubah. Estetika futuristik yang terinspirasi oleh imajinasi tentang bagaimana sebuah era membayangkan masa depan, mengambil budaya dan estetika era tersebut dan mengimajinasikan visualnya ke masa depan disebut sebagai Retro-Futurisme. "Jika futurisme kadang-kadang disebut sebagai" sains" yang cenderung mengantisipasi apa yang akan datang, retrofuturisme adalah yang menggambarkan perasaan dari antisipasi tersebut." E. Menurut Guffey, (2014) mengemukakan bahwa ditandai dengan perpaduan "gaya retro" kuno dengan teknologi futuristik, Retro-Futurisme mengeksplorasi berbagai antara masa lalu dan masa depan. 
Animasi adalah suatu pengambilan gambar statis yang berurutan, baik menggunakan gambar ataupun foto dan memutarnya secara berurutan untuk meniru gerakan. Karena mata manusia hanya dapat menyimpan gambar selama 1/16 detik, ketika beberapa gambar muncul secara berurutan dengan cepat, otak memadukannya menjadi satu gambar yang bergerak. Dalam animasi tradisional, gambar dibuat pada lembaran seluloid transparan untuk difoto dan ditampilkan pada film, dengan berkembangnya teknologi, sekarang sebagian besar dari animasi dibuat dengan menggunakan program komputer yang disebut sebagai digital painting dan CGI. Untuk menciptakan kesan gerakan halus dari animasi yang dibuat, terdapat sebutan FPS atau frames per second yang merupakan kecepatan frame, atau jumlah gambar berurutan yang ditampilkan pada setiap detiknya. Dalam film, FPS yang biasa digunakan untuk membuat animasi halus adalah 24 frame per detik. Ada beberapa jenis animasi yang menggunakan berbagai teknik berbeda untuk mencapai efek yang diinginkan: Animasi tradisional (cel animation), Animasi 2D (digital \& vektor), Animasi 3D, Motion Graphic, Stop Motion.

Animation Pipeline merupakan rencana terperinci mengenai bagian-bagian pembuatan animasi untuk mempermudah proses dalam pembuatan suatu proyek. Saat mempertimbangkan jalan kerja dalam pembuatan sebuah animasi, penting untuk mengetahui langkah-langkah yang akan dilakukan selama proyek berjalan. Baik animasi tradisional, 2D, 3D atau stop motion memiliki garis besar pipeline yang sama yaitu bagian pra-produksi, produksi, dan pasca-produksi. Pra-produksi merupakan langkah pertama dalam pembuatan animasi. Bagian ini adalah bagian di mana semua perancangan dilakukan sebelum mulai produksi animasinya. Bagian yang masuk dalam pra-produksi termasuk pembuatan: skrip, storyboard, rekaman audio, desain konsep (karakter, lingkungan, property, dan lain-lain), color script, animatic.

1. Skrip: Pembuatan skrip dan cerita merupakan bagian pertama dari bagian produksi. Dalam perusahaan perfilman terdapat sebuah tahap sebelum pipeline dapat dimulai yang disebut sebagai pitching yang merupakan presentasi verbal yang ringkas dari sebuah ide untuk film atau serial TV yang umumnya dibuat oleh penulis skenario atau sutradara film kepada produser film atau eksekutif studio dengan harapan menarik dana pembangunan untuk membayar penulisan skenario. Jadi, studio sudah mengetahui garis besar ide cerita sebelum proyek animasi dimulai. Berdasarkan ide cerita yang dipilih, kemudian bagian lain mulai diproduksi.

2. Storyboard: Storyboard adalah representasi visual dari semua adegan dan aksi yang ada di dalam skrip, dialog, latar belakang, catatan action scene, dan karakter-karakter yang disertakan pada bagian tertentu. Bagian storyboard sering kali dibuat bersamaan dengan desain konsep karakter, properti, desain lokasi, dan rekaman audio. Storyboard berfungsi untuk memberikan representasi dari letak, posisi, rencana gerakan karakter dan objek sebelum dibuat menjadi animasi yang matang.

3. Audio: Skrip diperlukan untuk rekaman dialog serta penambahan efek suara lainnya. Para aktor akan merekam suara mereka memerankan karakter yang terdapat dalam cerita dengan membaca bagian dialog berdasarkan skrip yang sudah ditentukan. Audio hasil rekaman dalam bagian ini nantinya akan digunakan untuk animatic, animasi, dan compositing.

4. Desain Konsep: Sebelum pembuatan animasi, background, atau pemberian warna dapat dilakukan, desainnya secara keseluruhan dilakukan terlebih dahulu. Setelah desain dan gaya gambar sudah ditentukan dan disetujui, proses berlanjut pada pembuatan lembar model yang mencakup desain dalam setiap elemen animasi, termasuk karakter, properti dan latar belakang, beserta segala jenis efek visual tambahan. Setiap lembar model terdiri dari desain akhir dengan proporsi ukuran karakter, berfungsi sebagai referensi standar selama proses animasi, untuk mempertahankan tampilan dan nuansa yang konsisten untuk setiap karakter.

5. Animatic: Bagian animatic dibuat langsung dari storyboard. Animatic adalah rangkaian bentuk video pertama dari sebuah proyek dan digunakan untuk membantu animator dan kompositor. Storyboard dipasang dengan suara dan dialog, belum dengan animasi yang halus untuk membantu mengevaluasi tindakan dasar dan sudut pertunjukan. Pembuatan animatic 
ini tidak diperlukan jika sudah memiliki kepastian dengan storyboard yang dibuat.

Produksi adalah langkah proses pembuatan animasi dikerjakan, menggunakan hasil dari pra-produksi sebagai dasarnya. Ada beberapa langkah dan cara untuk melakukan bagian produksi yang berbeda, ketika membuat animasi 3D, 2D, tradisional atau stop-motion, karena ini adalah bagian di mana animasi diproduksi sebelum tahap pasca-produksi dan tahap finalisasi. Proses produksi sekarang yang menggunakan cara digital merupakan cara yang jauh lebih mudah, cepat, dan efektif. Menggunakan tablet gambar dan program digital painting, karakter dan latar belakang digambar secara terpisah. Berdasarkan animatic dan storyboard yang sudah dibuat terlebih dahulu, tahap produksi termasuk pembuatan latar belakang, gerakan aktivitas karakter, membuat sketsa animasi kasar, membersihkan sketsa animasi (outline cleanup), membuat inbetween (membuat frame transisi antar keyframe untuk menghasilkan animasi yang halus), mewarnai gambar dengan bantuan program digital, compositing, dan akhirnya mengekspor hasil render. Bagian pasca-produksi merupakan tahapan terakhir dari animation pipeline, tahapan yang berfungsi untuk compositing dan penggabungan hasil dari tahapan pra-produksi dan produksi. Karakter-karakter sudah diberikan warna, dianimasikan, dan ditempatkan pada latar belakangnya. Setiap adegan telah disusun, diwarnai, dan animasinya pada dasarnya sudah selesai dan digabungkan menjadi satu bagian. Kemudian dalam tahapan ini mengedit dan memoles produk akhir dengan pemberian visual effects (vfx), efek suara, color correction, dan lain-lain untuk menyempurnakan hasil akhir dari animasinya.

\section{METODE PENELITIAN}

Dalam penelitian ini pendekatan yang dilakukan adalah pendekatan kualitatif data yang dikumpulkan bukan merupakan data dalam bentuk angka atau numerik melainkan berupa data dari berbagai macam buku dan artikel mengenai perkembangan teknologi dan hubungan sosial dalam keluarga, beserta contoh referensi berbagai film dan visual yang menunjukkan dunia futuristik. Hal ini menjadi tujuan dari penelitian kualitatif ini adalah untuk menghasilkan deskripsi dan visual yang mendetail tentang hal yang sedang diteliti.

Untuk memproduksi penelitian ini, penulis membuat pipeline dalam pembuatan agar rencana produksi tersusun dengan rapi. Metode produksi animasi ini adalah dengan teknik digital dalam bentuk 2D.

\section{HASIL DAN PEMBAHASAN}

\section{Data Hasil Riset Observasi}

Berdasarkan estetika Retro-Futurisme, penulis memutuskan untuk mendasarkan semua visual dari estetika Cyberpunk, karena alur cerita yang cocok dengan tema Cyberpunk yaitu menceritakan mengenai bayangan dunia utopia di mana masyarakat didominasi oleh teknologi. Penulis kemudian menonton dan menganalisa beberapa film dan gameplay yang terkenal dengan menggunakan estetika visual Cyberpunk. Beberapa film yang penulis nonton untuk penelitian ini berupa: Akudama Drive, Akira, game Cyberpunk 2077 dan Detroit: Becomes Human. Dalam hal visual lingkungan, film dan game tersebut bertempat dalam kota besar, kota dengan gedunggedung yang tinggi dan lampu-lampu yang sangat cerah, neon dan mencolok. Kemudian juga sering menggunakan bentuk-bentuk geometris dalam visualnya, baik dalam lingkungan, art style maupun bentuk aksesoris dalam pakaian yang dikenakan oleh penduduk.

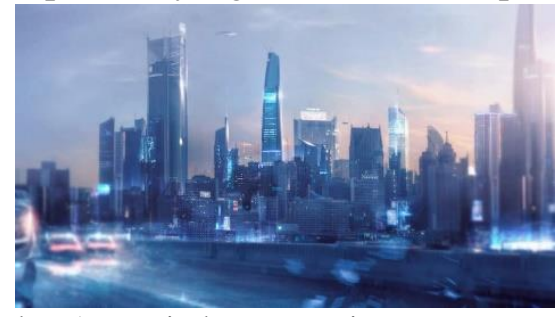

Gambar 1 Desain kota Detroit: Becomes Human 
Banyak adegan dalam film berlangsung pada malam hari untuk menekankan sorotan pada lampu-lampu neon yang juga berwarna cerah dengan warna merah, biru, dan ungu sebagai warna yang biasa digunakan. Selain itu, dalam hal fashion karena cerita dalam genre Cyberpunk memiliki alur cerita dan tokoh utama yang membawa "semangat pemberontakan", pakaian yang dikenakan terlihat menggunakan inspirasi dari style "street-fashion" baik dari jaket, sepatu bot, sarung tangan, dan lain-lain. Estetika Cyberpunk juga sering menggunakan hologram dan banyak robot karena latar dunia Cyberpunk yang dalam lingkungan penuh dengan teknologi. Baik itu robot sungguhan atau robot setengah manusia yang disebut cyborg.

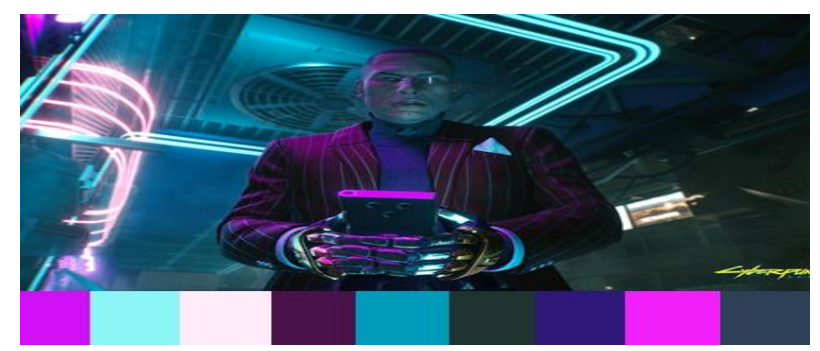

Gambar 2 Color Palette dalam Cyberpunk 2077

\section{Penyajian dan Analisis Data}

Dalam penyajian data ini, penulis akan menguraikan hasil data dari wawancara yang dilakukan bersama dengan Dr. Jim Taylor, Ph. D yang memiliki keahlian profesional dalam hal psikologi kinerja, olahraga, dan pengasuhan anak. Dr. Jim Taylor juga menulis artikel berjudul "Is Technology Creating a Family Divide?" yang menjadi salah satu sumber utama dalam laporan ini. Hasil data yang diperoleh dapat diuraikan dalam poin-poin sebagai berikut:

1. Jika orang tua dan anak-anaknya kecanduan teknologi, akan sangat sulit untuk mengubah budaya teknologi dalam keluarga. Pertama, orang tua tidak dapat melihat masalahnya dalam penggunaan teknologi berlebihan. Kedua, jika mereka melihatnya sebagai masalah, mereka harus mengubah perilaku mereka terhadap teknologi terlebih dahulu. Jika orang tua dan anakanak melihat pentingnya mengurangi penggunaan teknologi, maka mungkin (meskipun sangat sulit mengingat sifat kecanduan) untuk memperbaiki perilaku terhadap teknologi dalam keluarga.

2. Dapat diperkirakan kalau masa depan tidak cerah dalam hal penggunaan teknologi. Orang tua sekarang masih hidup ketika tidak ada internet, karena itulah mereka memiliki berbagai perspektif mengenai perkembangan teknologi. Generasi berikutnya hanya akan mengetahui minat dan penggunaan teknologi. Tentunya untuk kedepannya akan terdapat banyak tantangan psikologis, emosional, sosial, dan budaya yang akan muncul. Namun, tidak berarti bahwa tidak akan ada banyak hal positif yang akan datang dari penggunaan teknologi, seperti yang dapat kita lihat sekarang ini, tetapi juga akan ada masalah yang signifikan.

3. Terdapat banyak sekali bukti bahwa penggunaan teknologi yang berlebihan berdampak negatif pada anak-anak secara psikologis, emosional, sosial, dan pendidikan.

4. Dengan peningkatan pendapatan yang dapat dibelanjakan dan meningkatnya pentingnya status telah menghasilkan rumah yang lebih besar yang, menurut definisi, berarti bahwa keluarga tidak akan sering bertemu satu sama lain, sehingga meningkatkan kesenjangan. Bahkan orang-orang yang tidak memiliki banyak uang akhir-akhir ini adalah orang yang aspiratif, artinya mereka menginginkan lebih dan lebih besar, walaupun mereka tidak mampu membelinya.

5. Teknologi baru, yang digerakkan oleh internet lebih kuat daripada, teknologi yang diciptakan sebelumnya seperti contohnya televisi karena smartphone telah membuat informasi, komunikasi, dan hiburan menjadi portabel. Teknologi modern (ingat bahwa mesin cetak adalah teknologi pada zamannya dan dipandang sebagai ancaman bagi 
masyarakat juga) ada bersama kita setiap hari. Selain itu, teknologi digital telah dirancang untuk membuat ketagihan (tidak hanya secara psikologis, tetapi juga secara neurologis seperti obat-obatan, alkohol, dan perjudian). Perusahaan teknologi besar menghabiskan miliaran dolar setiap tahun untuk mengembangkan apa yang disebut teknologi persuasif yang membuat kita kecanduan media sosial, game, dan lain-lain.

\section{Sinopsis Cerita}

Di masa depan di mana teknologi maju telah mengambil alih masyarakat, terdapat keluarga yang terdiri dari empat orang. Keluarga yang tidak benar-benar berinteraksi satu sama lain. Nova, ibu yang tergila-gila dengan akun media sosialnya, Tony, ayah yang gila kerja, Annette yang suka main game, dan Theo yang kesepian. Seumur hidup Theo tidak pernah merasakan kehangatan dan kasih sayang dari keluarganya. Dia hanya didampingi oleh robot pengurusnya yang bernama EGGBOT. Suatu hari, EGGBOT rusak dan tidak bisa dinyalakan. Dengan panik Theo mencari anggota keluarganya untuk meminta bantuan. Sayangnya mereka semua sibuk dengan urusan mereka sendiri, mengabaikan Theo yang dalam kesulitan. Saat itu, listrik mati mematikan semua yang ada di dalam rumah dan semuanya berlari ke ruang tamu untuk mengetahui apa yang telah terjadi. Kemudian terdapat pengumuman yang mengatakan bahwa ada beberapa masalah teknis dan untuk semuanya tetap tenang karena masalahnya akan diselesaikan dalam waktu yang singkat. Semuanya dengan canggung duduk dan menunggu. Setelah beberapa saat, Theo ingat dia membawa sebuah mainan berbentuk kubus yang bisa dimainkan dan semua orang akhirnya bergabung. Theo tidak perah merasa sebahagia ini sebelumnya, meskipun saat itu sangat cepat berlalu karena listrik mulai menyala kembali. Semuanya kembali melakukan halnya masing-masing meninggalkan Theo sendirian, tapi kemudian EGGBOT menyala dan menemani Theo yang menjadi kesepian kembali.

\section{Eksplorasi Desain Karakter}

Penulis ingin menekankan pada hubungan keluarga yang rusak karena pengaruh penggunaan teknologi secara terus-menerus, kemudian penulis membuat 4 anggota keluarga di mana setiap anggota melambangkan suatu efek negatif hasil terlalu banyak mengonsumsi teknologi. Saat menggambar sketsa dari awal penulis sudah memutuskan untuk membuat karakter dengan style semi-realistis, untuk membuat kesan dunia futuristik yang tampak seperti dunia fantasi namun tetap terlihat kesan nyatanya. Saat mencari referensi art style, penulis memutuskan untuk memilih referensi dari serial animasi Carmen Sandiego, serta referensi dari berbagai karya hasil Kevin Dart. Baik Carmen Sandiego dan Kevin Dart memiliki gaya yang sederhana namun semi-realistis, serta warna dengan style lighting yang sangat mencolok, bentuk yang simple, minimalis, dan lancip.

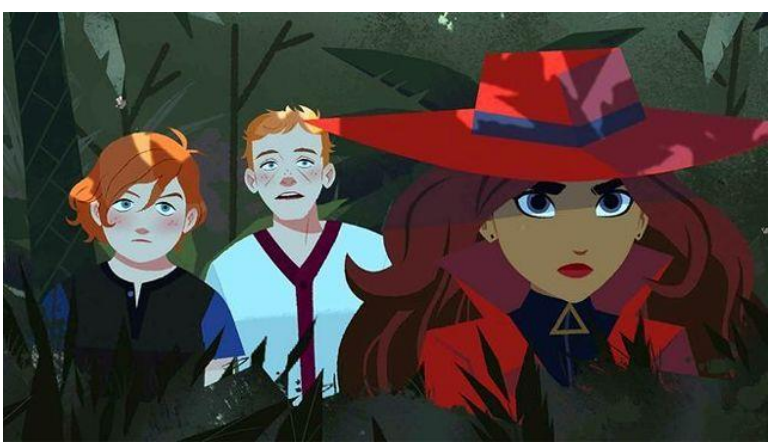

Gambar 3 Referensi artstyle seri Carmen Sandiego

\section{Perancangan tokoh karakter}

Karakter 1: Nova 
Karakter Nova, ibu dari keluarga dan pecandu media sosial. Nova adalah seorang yang keras kepala dengan kepribadian bermuka dua, di mana dia bertindak baik dan lembut kepada followersnya tetapi pada kenyataannya dia mudah marah. Karena diabaikan oleh suaminya yang sibuk, Nova mencari perhatian orang lain dari media sosial dan akhirnya populer dengan lebih dari 1 juta pengikut. Sekarang, seorang influencer fashion online, Nova sangat memperhatikan penampilan, tren dan followersnya lebih dari apa pun.

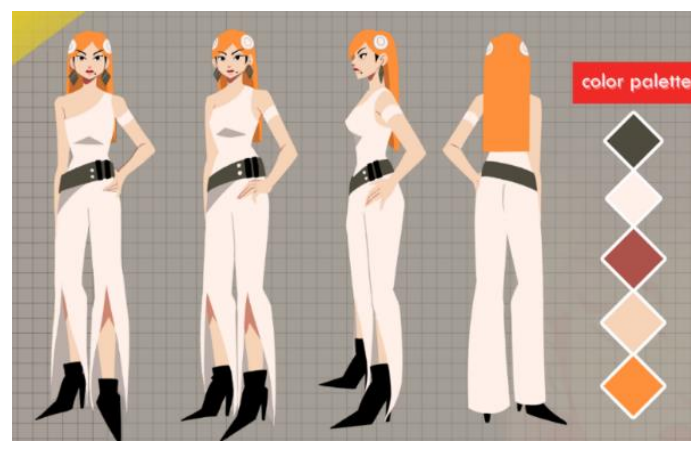

Gambar 4 Konsep karakter Nova

Berdasarkan penelitian, seorang yang memiliki kecanduan tinggi terhadap media sosial, adalah seorang yang menginginkan perhatian dan penerimaan dari orang lain. Oleh karena itu, Nova memiliki desain yang menonjol dibandingkan dengan anggota keluarganya lainnya. Nova memiliki rambut oranye cerah yang membedakannya di antara keluarganya yang berambut hitam, dan memakai pakaian terbuka yang menunjukkan bahwa dia sangat percaya diri. Dia peduli dengan penampilannya lebih dari apapun oleh karena itulah dia mengikuti berbagai tren fashion terkini. Untuk ini penulis mencari tren fashion yang tenar dikalangan media sosial saat ini. Desain baju yang dipilih terlihat sangat tidak nyaman untuk menunjukkan betapa bersedianya karakter ini dalam mengikuti tren dan mendapatkan followers. Celananya memiliki potongan besar yang tidak berguna di bagian depan, tumit sepatu hak yang sangat tinggi dan tajam, serta aksesoris untuk melengkapi penampilannya.

\section{Karakter 2: Annette}

Annette adalah anak sulung dan putri dalam keluarga cerita ini. Meniru deskripsi kehidupan nyata dari "gamer" yang memiliki kecanduan game berlebihan, dia akan menghabiskan waktu di dalam kamarnya sepanjang hari hanya untuk bermain game. Desainnya dibuat agar terlihat sangat berlawanan dengan ibunya yang cerah, menonjol, dan rapi.

Desainnya menunjukkan penampilan dengan rambut panjang yang berantakan, jaket kebesaran, dan kaus kaki yang beda panjangnya. Penulis memutuskan rambut panjang untuk menekankan ketidakrapiannya. Pakaiannya berwarna redup berlawanan dengan desain Nova kecuali jaketnya dengan garis-garis biru cerah yang berasal dari merchandise game yang dibelinya. Dia juga memakai headphone serta dua konsol game yang melayang di atas kepalanya untuk membuatnya terlihat lebih mirip gamer. Desain Annette dibandingkan dengan anggota keluarganya paling menekankan tampilan estetika Cyberpunk.

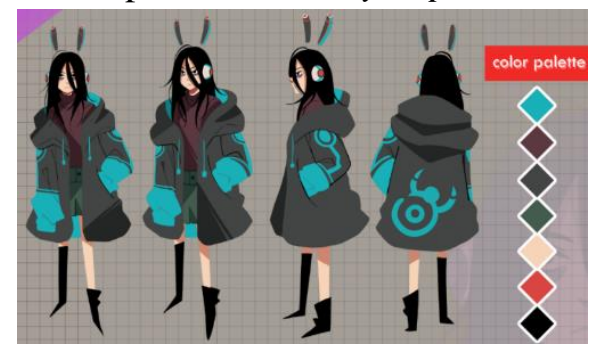

Gambar 5 Konsep karakter Annette 
Karakter 3: Tony

Karakter ayah yang merupakan seorang workaholic atau gila kerja yang lebih fokus pada pekerjaannya dibandingkan dengan keluarganya sendiri, juga salah satu penyebab utama mengapa Nova menjadi sangat kecanduan media sosial. Orang tua, adalah tulang punggung keluarga, jika yang satu runtuh maka hubungan keluarga tidak dapat berjalan dengan lancar. Kecenderungan gila kerja Tony juga merupakan salah satu aspek dari pengaruh kecanduan yang mengakibatkan rusaknya hubungan dalam keluarga. Desain akhir Tony berpenampilan lebih ramping serta posisi yang lebih membungkuk menunjukkan postur badan yang buruk saat bekerja. Desain bajunya juga terinspirasi dari street fashion Jepang untuk membuat tampilan yang futuristik tetapi pada saat yang sama terlihat nyaman. Palet warnanya menggunakan kombinasi dari warna abu-abu untuk menekankan rasa monotonnya.

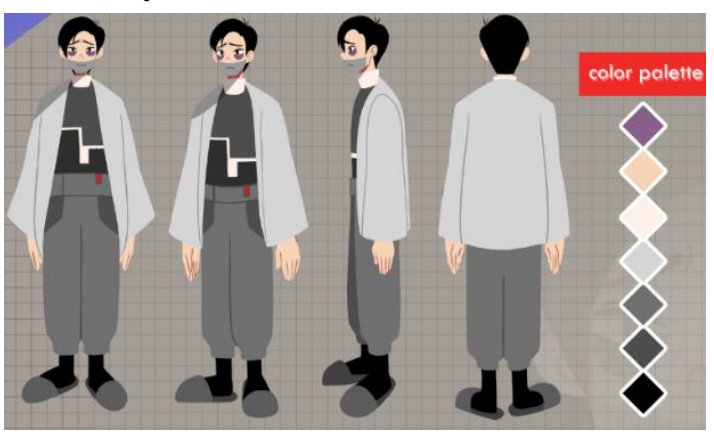

Gambar 6 Konsep karakter Tony

\section{Karakter 4: Theo \& EGGBOT}

Ide dari pembuatan karakter Theo berasal dari observasi penulis, di mana orang tua yang sibuk sekarang cenderung memberikan gadget pada anak-anak di usia yang sangat muda untuk membuat mereka tetap tenang, walaupun mengetahui kalau gadget tidak baik untuk tahap awal perkembangan anak. Theo adalah hasil dari memiliki orang tua yang tidak memedulikannya.

EGGBOT adalah robot yang bertanggung jawab untuk mengurus kebutuhan Theo sementara orang tuanya tidak dapat merawatnya. EGGBOT memiliki tampilan sederhana dengan bentuk tubuh yang bulat dan dua antena yang melayang di sekitar badan utamanya. Saat melihat referensi untuk robot, banyak robot dari film animasi yang berbentuk semi-manusia, mereka berukuran besar memiliki tubuh dan dapat berinteraksi dengan baik dengan manusia. Tapi berdasarkan jalan cerita film ini, penulis ingin menekankan betapa kesepiannya Theo tanpa kehadiran anggota keluarganya. Oleh karena itu, EGGBOT didesain sebagai robot berbentuk sederhana untuk memperlihatkan adanya batasan yang bisa dilakukan oleh robot yang hanya bisa dicapai oleh manusia. Desain dasar EGGBOT mereferensi desain dan fitur mainan anak-anak "Tamagotchi". Tamagotchi adalah game sederhana dimana mekanisme utamanya adalah merawat hewan peliharaan virtual dengan memberi makan, bermain, memandikannya, dan membuatnya tidur. Selama pemain dapat mengawasi hewan peliharaan dan melakukan hal-hal tersebut secara teratur, maka peliharaan virtual tersebut dapat tumbuh secara normal. Desain dan fungsi EGGBOT yang mereferensi Tamagotchi juga menunjukkan sisi ironis dari perkembangan teknologi di mana sekarang robot memiliki kemampuan untuk mengurus anak, bukan sebaliknya.

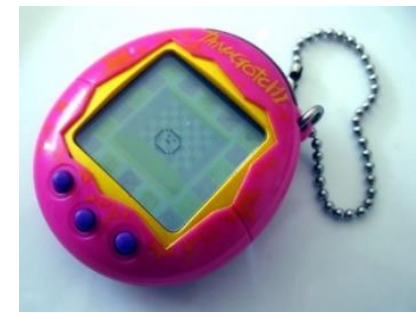

Gambar 7 Referensi bentuk Tamagotchi 
Ide Desain Theo didasarkan dari deskripsi karakter "anak yang diabaikan oleh keluarganya". Theo memiliki rambut panjang tapi rapi, serta pakaian yang longgar karena EGGBOT membelikannya untuknya. EGGBOT dan Theo didesain agar terlihat serasi sehingga ketika penonton melihat keseluruhan desain penonton dapat langsung mengetahui bahwa ada hubungan antara Theo dan karakter robot. Keduanya memiliki palet warna yang sangat mirip dan memiliki bentuk dasar bulat.

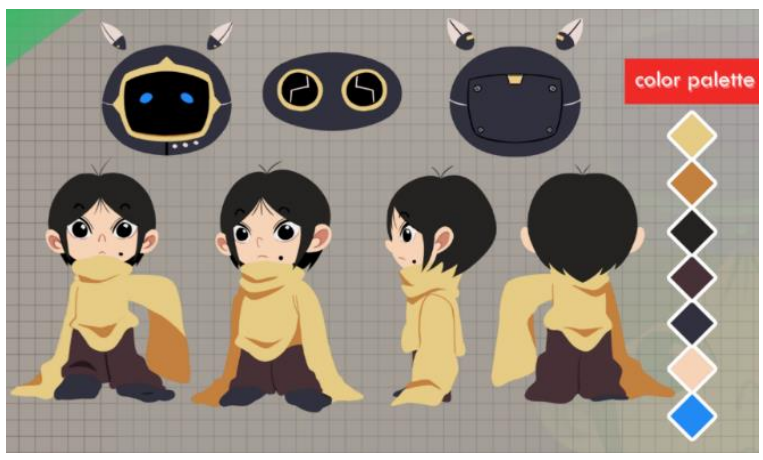

Gambar 8 Konsep karakter Theo \& EGGB

\section{Desain Keseluruhan}

Mengenai keseluruhan desain keluarga, setiap karakter didesain agar setiap karakter dapat menonjol dengan caranya sendiri. Nova dengan penampilannya yang sangat berani, tampilan abu-abu netral Tony, tampilan Annette yang lebih terinspirasi Cyberpunk, dan Theo yang memiliki robot. Mereka masing-masing memiliki masalah dan kecanduannya sendiri dalam hal teknologi, tetapi mereka masih satu keluarga, jadi penulis mencoba membuat mereka memiliki suatu kemiripan yang menyatukan desainnya. Annette memiliki hidung ibunya yang mancung, dan mata ayahnya yang terkulai, sedangkan Theo memiliki mata yang lancip dan tahi lalat ibunya serta bentuk hidung ayahnya yang bundar. Seperti yang disebutkan sebelumnya, mereka adalah keluarga Asia sehingga semuanya memiliki rambut hitam kecuali Nova yang mewarnainya.

\section{Eksplorasi Desain Environment}

Berdasarkan hasil wawancara dengan Dr. Jim Taylor, Ph. D. yang mengatakan kalau kedepannya setiap orang berambisi memiliki rumah yang lebih besar, sehingga kamar-kamar juga semakin membesar dan menjauh. Untuk menekankan hal ini, penulis membuat denah rumah yang menunjukkan letak kamar tokoh masing-masing yang ditempatkan jauh dari kamar yang lainnya.

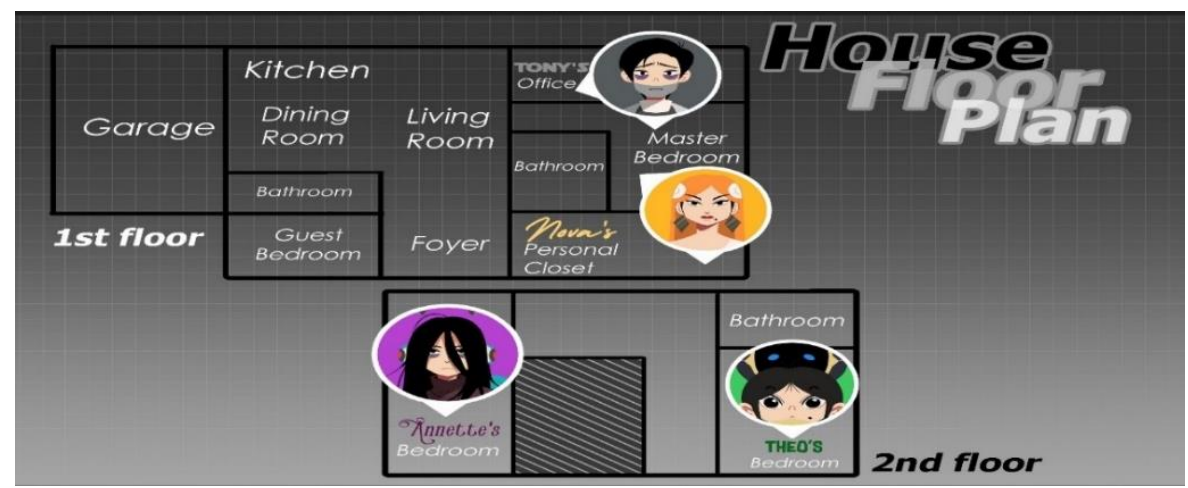

Gambar 9 Denah Rumah

Dalam ceritanya, akan terlihat juga kamar beberapa tokoh secara sekilas. Untuk itu penulis membuat desain kamar Theo, Annette dan kantor pribadi Tony. Setiap kamar didesain 
agar menunjukkan kepribadian masing-masing karakter. Kamar Theo sangat rapi dan diberi dekorasi tetapi tidak terlalu menunjukkan kepribadiannya, dia sekamar dengan EGGBOT jadi terdapat barang-barang yang terkait dengan EGGBOT. Kamar Annette sangat berantakan dan dipenuhi dengan berbagai games dan merchandise. Kemudian kantor Tony, sangat kosong dan tidak ada isinya. Untuk menambahkan kesan futuristik penulis memberi benda-benda seperti hologram dan robot dalam desain rumahnya. Serta membuat bentuk rumah lebih minimalis dan geometris sesuai dengan penelitian observasi.

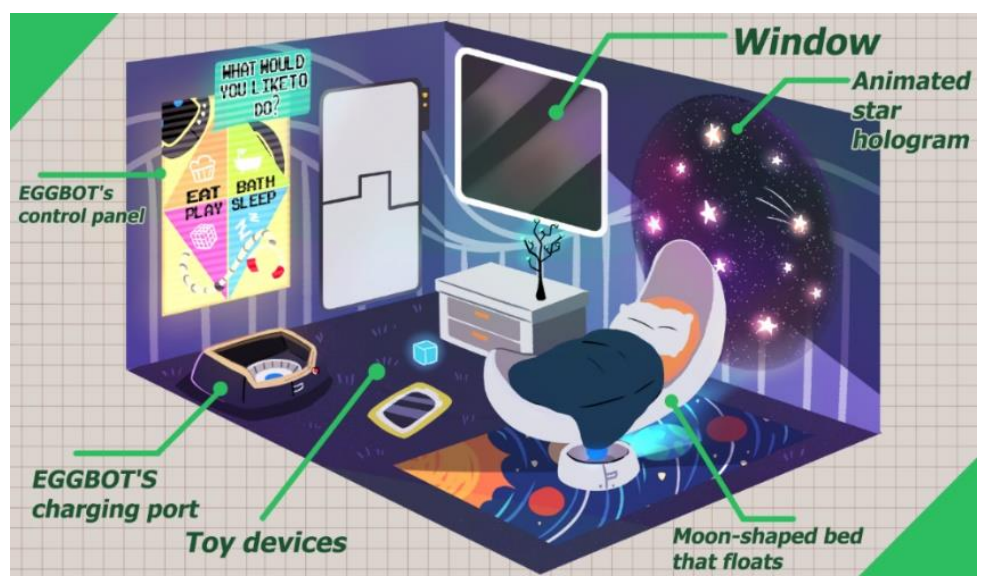

Gambar 10 Desain kamar Theo

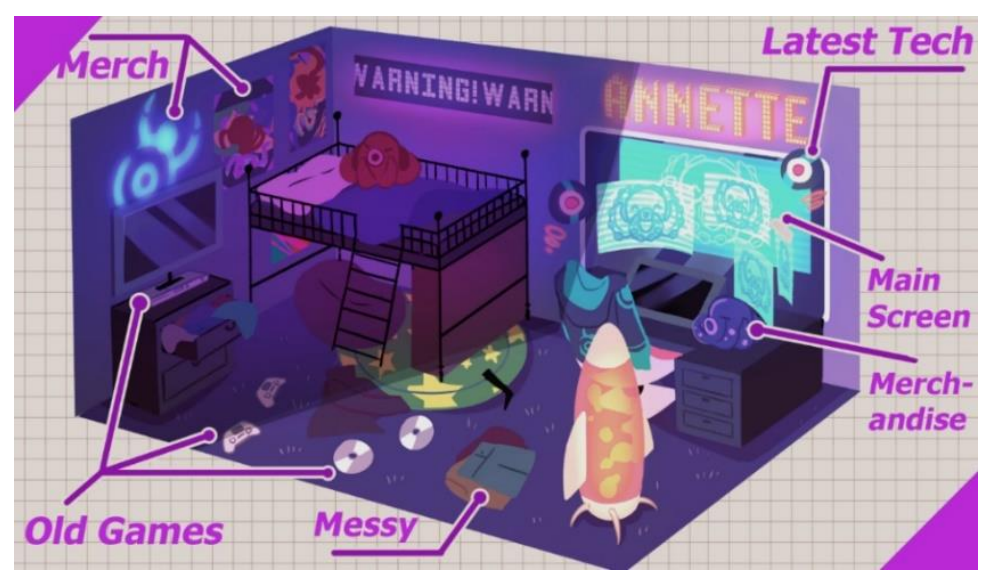

Gambar 11 Desain kamar Annette

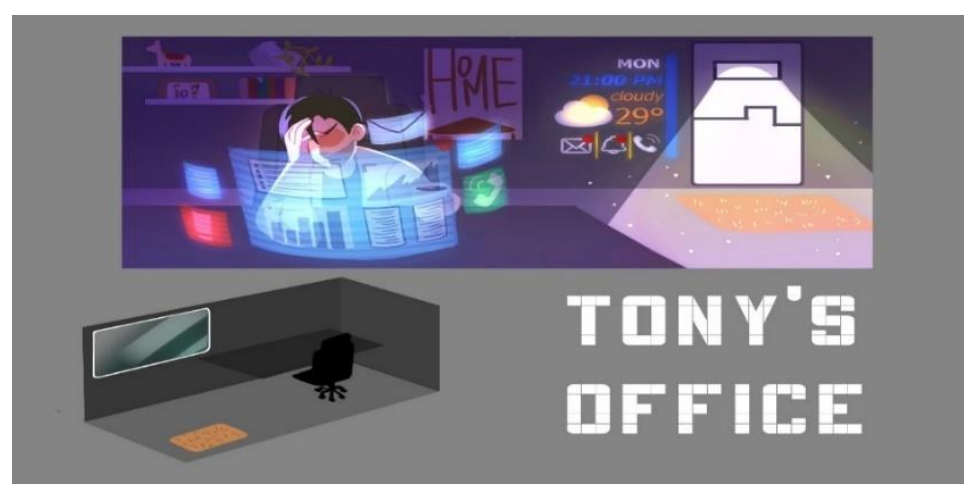

Gambar 12 Desain office Tony 


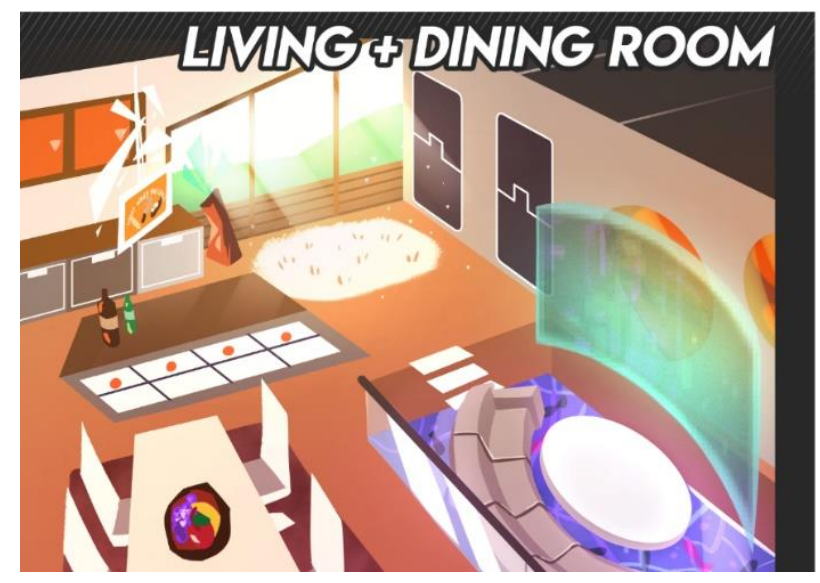

Gambar 13 Design living room dan dining room

\section{Eksplorasi Desain Environment}

Judul yang dipilih untuk animasi pendek adalah "Screens" atau layar yang melambangkan salah satu tema cerita dan riset tentang masa depan teknologi digital tapi juga sebagai istilah metafora menunjukkan adanya suatu perpisahan yang menyebabkan perpecahan keluarga. Referensi desain judul semuanya dari film yang memiliki latar di masa depan. Untuk menambahkan kesan "estetika Cyberpunk" font dasar yang dipilih memiliki bentuk yang tebal dan tajam. Dalam desain akhir terdapat suatu potongan besar di tengah, memecah judul menjadi 2 untuk menekankan kalau di dalam cerita terdapat semacam perpecahan atau pemisahan yang terlibat. Warna-warna cerah memberikan kesan yang lebih futuristik dan tampilan Cyberpunk

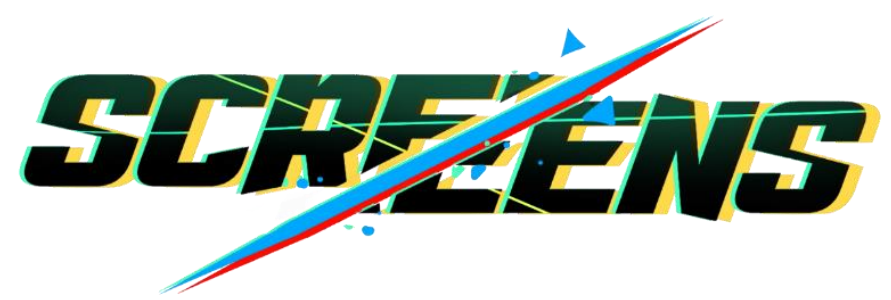

Gambar 14 Design judul animasi Screens

\section{SIMPULAN}

Teknologi merupakan suatu hal yang dapat mempermudah kehidupan manusia. Dengan adanya teknologi terdapat banyak hal yang bisa dicapai sekarang yang sebelumnya tidak. Walau begitu, menggunakan teknologi terus menerus dapat menghasilkan berbagai efek negatif. Salah satu efektif negatif tersebut adalah kurangnya interaksi dengan keluarga sendiri. Semakin berkembangnya teknologi, orang-orang semakin mengurung diri sibuk melakukan urusannya masing-masing. Mereka berkomunikasi dengan orang-orang secara online namun mereka tidak berinteraksi dengan orang-orang yang sebenarnya dalam hidup mereka. Hal ini sudah masuk dalam kategori kecanduan teknologi, dan jika tidak ada yang dapat melihat hal ini sebagai masalah maka pada akhirnya kecanduan hanya akan bertambah buruk. Oleh karena itu, penulis melihat pentingnya meningkatkan wawasan masyarakat sekali lagi mengenai bahayanya penggunaan teknologi secara terus menerus dan pentingnya itu hubungan yang dimiliki dalam keluarga. Dalam hal ini untuk membawakan pesan dalam cara yang menarik penulis membuat perancangan animasi yang menceritakan masalah dalam sudut pandang karakter yang hidup di masa depan ketika perkembangan teknologi sudah jauh lebih canggih dari yang terdapat sekarang. Untuk itu penulis mengobservasi berbagai film dan referensi visual untuk mengetahui cara membentuk dan membuat dunia futuristik yang terlihat menarik. 
Selama melakukan riset penulis juga mengobservasi banyaknya estetika yang terdapat dalam visual futuristik. Setiap tema tersebut menggunakan berbagai pengaruh dari tren yang terdapat pada eranya masing-masing baik itu dalam hal teknologi maupun gaya pakaian. Dalam hal pembuatan visual yang terlihat futuristik dengan menambahkan pengaruh dari era digital yang sekarang ini Cyberpunk merupakan estetika yang paling sesuai.

\section{DAFTAR PUSTAKA}

2D animation: Everything you should know about. (2019). Diterima dari https://www.renderforest.com/blog/2d-animation

Aesthetics Wiki. Retro-futurism. Diterima dari .https://aesthetics.fandom.com/wiki/Retro Futurism.

Ancok, D. (2000). Psikologi dan tantangan milenium ketiga: Dampak teknologi internet pada kehidupan manusia dan pengelolaan institusi pendidikan psikologi. Psikologika: Jurnal Pemikiran dan Penelitian Psikologi, 5(9), 5-16.

Animation Workflow. (2017). Diterima dari https://learn.toonboom.com/modules/animationworkflow

Bozoglan, B. (2018). Psychological, Social, and Cultural Aspects of Internet Addiction. United States of America: IGI Global.

FCD Prevention Works. (2017). Technologi Addiction. Diterima dari https://www.hazeldenbettyford.org/articles/fcd/teen-technology-addiction

Gobelins. (2019, Juni 28). Making of Best Friend - Part 1: The story (Animation Short Film 2018). Diterima dari https://www.youtube.com/watch?v=YRHQpiPoswY

Gobelins. (2019, September 13). Making of Best Friend - Part 2: Visual development-(Animation Short Film 2018). Diterima dari https://www.youtube.com/watch?v=eNNqss6qLtA

Greenfield, S. (2015). Mind Change: How Digital Technologies are Leaving Their Marks on Our Brains.United States of America: Random House.

Imagic Institute. (2018). The 2D Animation Process. Diterima dari https://imagic.net.in/blog/2danimation-process

Maio, A. (2020). What is Animation? Definition and Types of Animation. Diterima dari https://www.studiobinder.com/blog/what-is-animation-definition/

Novak, M. (2012). Googie: Architecture of the Space Age. Diterima dari https://www.smithsonianmag.com/history/googie-architecture-of-the-space-age$122837470 /$

Putri, G. S. (2018). WHO Resmi Tetapkan Kecanduan Game Sebagai Gangguan Mental. https://sains.kompas.com/read/2018/06/19/192900123/who-resmi-tetapkan-kecanduangame-sebagai-gangguan-mental

Taylor, J. (2013). Is Technology Creating a Family Divide? Diterima dari https://www.psychologytoday.com/us/blog/the-power-prime/201303/is-technology- 
creating-family-divide

Weinschenk, S. (2014). Are You Addicted To Texting? Diterima dari https://www.blog.theteamw.com/category/social-media/

World Health Organization. (2018). Gaming Disorder. Diterima darihttps://www.who.int/westernpacific/news/q-a-detail/gaming-disorder 